\title{
End-Functionalized Poly(vinylpyrrolidone) for Ligand Display in Lateral Flow Device Test Lines
}

\author{
Alexander N. Baker, Thomas R. Congdon, Sarah-Jane Richards, Panagiotis G. Georgiou, Marc Walker, \\ Simone Dedola, Robert A. Field, and Matthew I. Gibson*
}

Cite This: https://doi.org/10.1021/acspolymersau.1c00032

Read Online

\section{ACCESS |}

山ll Metrics \& More

回国 Article Recommendations

(s) Supporting Information

ABSTRACT: Lateral flow devices are rapid (and often low cost) point-of-care diagnostics-the classic example being the home pregnancy test. A test line (the stationary phase) is typically prepared by the physisorption of an antibody, which binds to analytes/antigens such as viruses, toxins, or hormones. However, there is no intrinsic requirement for the detection unit to be an antibody, and incorporating other ligand classes may bring new functionalities or detection capabilities. To enable other (nonprotein) ligands to be deployed in lateral flow devices, they must be physiosorbed to the stationary phase as a conjugate, which currently would be a high-molecular-weight carrier protein, which requires (challenging) chemoselective modifications and purifica-

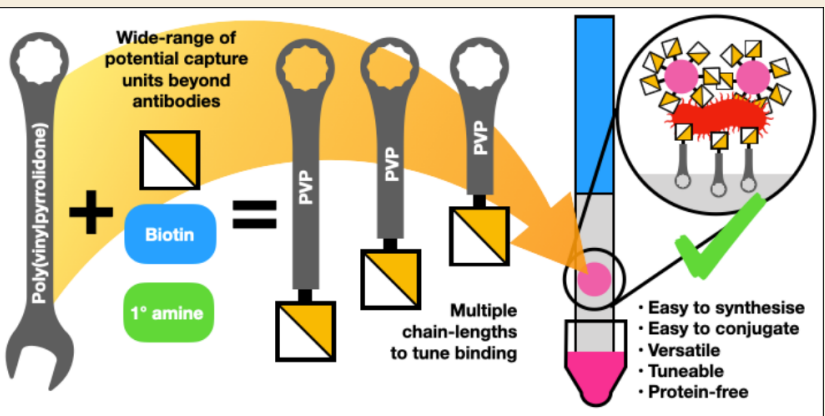

OUT WITH THE PROTEIN, IN WITH THE POLYMER - PROTEIN-FREE LATERAL FLOW tion. Here, we demonstrate that poly(vinylpyrrolidone), PVP, is a candidate for a polymeric, protein-free test line, owing to its unique balance of water solubility (for printing) and adhesion to the nitrocellulose stationary phase. End-functionalized PVPs were prepared by RAFT polymerization, and the model capture ligands of biotin and galactosamine were installed on PVP and subsequently immobilized on nitrocellulose. This polymeric test line was validated in both flow-through and full lateral flow formats using streptavidin and soybean agglutinin and is the first demonstration of an "all-polymer" approach for installation of capture units. This work illustrates the potential of polymeric scaffolds as anchoring agents for small-molecule capture agents in the next generation of robust and modular lateral flow devices and that macromolecular engineering may provide real benefit.

KEYWORDS: lateral flow assay, polymers, RAFT, glycans, diagnostics, biosensing

\section{INTRODUCTION}

Lateral flow devices (LFDs) are point-of-care (POC) diagnostics that are suited to primary care, triage, and emergency applications. ${ }^{1}$ The most widely known LFD is the home pregnancy test, which detects the presence of the hormone human chorionic gonadotrophin (HCG) in urine in under $20 \mathrm{~min}^{2,3}$ In these devices, the stationary phase of the LFD is nitrocellulose functionalized with an antibody that binds HCG. Gold nanoparticles (AuNPs) functionalized with the same antibody are in the mobile phase. This leads to the sandwiching of HCG between the immobilized antibody on the device surface and the antibody on the AuNPs, producing an optical signal-often a red line; notably, other signal producing elements can be used such as quantum dots, ${ }^{4}$ graphene oxide, ${ }^{5,6}$ and carbon nanotubes.

LFDs have many applications beyond detecting HCG; for example, they have been deployed for analytes such as drugs of abuse, ${ }^{8}$ Ebola virus, ${ }^{9}$ meningitis, ${ }^{10}$ and SARS-COV-2. ${ }^{11}$ The common design principle shared by the above tests is they all use antibodies as capture agents (lateral flow immunoassays) due to the very high affinity and selectivity of antibodies toward their ligands (in the range of $\mathrm{nM}$ to $\mathrm{pM}$ ). Despite the ubiquity of antibodies in LFDs, there is no functional requirement that these be used as the capture agent. There are examples of LFDs that use protein-anchored nucleotides, ${ }^{12}$ protein-anchored glycans, ${ }^{13}$ and lectins ${ }^{14}$ as capture agents in the mobile phase and as test lines in the stationary phase. There are potential benefits of using alternative ligand capture molecules. For example, Baker et al. have demonstrated that the spike protein from SARS-COV-2 (causative agent of COVID-19) can be detected in a lateral flow/flow-through setup by using $N$-acetyl neuraminic acid (NeuNAc, a glycan) as the recognition agent but required a glycosylated protein as the test line. ${ }^{13}$ The same system could be deployed in flow-

Received: September 9, 2021

Revised: October 25, 2021

Accepted: October 26, 2021 
A

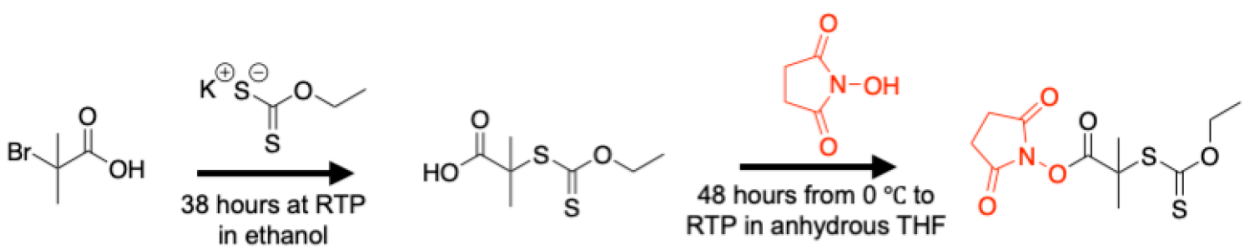

B

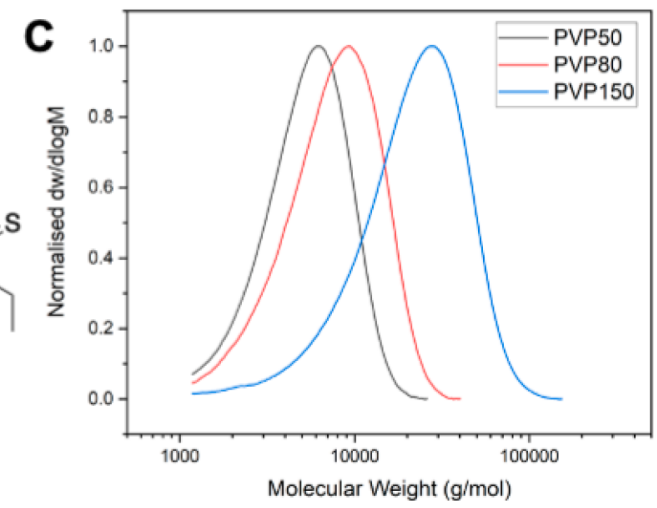

Figure 1. Polymer synthesis. (A) Synthesis of MADIX chain-transfer agent (CTA); (B) polymerization of N-vinylpyrrolidone (NVP); (C) normalized molecular weight distributions from size exclusion chromatography of PVP polymers from Table 1.

through (no test line) to detect COVID-19 positives in primary patient swab samples. ${ }^{15}$

Miura et al. have made hybrid LFDs to detect plant proteins, using glycosylated nanoparticles as the mobile phase but still using an antibody as the test line. ${ }^{16}$ By moving away from (or combining with) antibody-based detection, it may be possible to more rapidly develop new LFDs, by enabling the development of fully synthetic systems removing the need to raise antibodies (in, e.g., animal models). This new approach could allow for easier manufacture (including scaling) as well as bringing additional discriminatory power to tests.

Nearly all current LFDs use antibodies (lateral flow immunoassays) as the stationary phase (as well as the mobile phase) or use proteins that are functionalized with other ligands, such as nucleic acids, in the stationary phase. These approaches lead to three fundamental challenges. First, the molecular weight of the test-line conjugate must be large enough to attach to the surface, with absorption ability decreasing with decreasing molecular weight, limiting scope to very high-molecular-weight macromolecules. ${ }^{17,18}$ This limit can be overcome by increasing the surface area of the stationary phase membrane, although this limits the choice of stationary phase membrane material. ${ }^{19}$ Second, bovine serum albumin (BSA) or other proteins must be used as "anchors" to immobilize small capture agents such as nucleotides or glycans onto the surface of an LFD; this is further limited by the small number of easy-to-use chemical conjugations available to functionalize carrier proteins. Moreover, the chemical conjugation approaches used do not provide a clear picture of the number of capture units per protein. For example, when using glycan-functionalized BSA, a range of degrees of glycosylation are obtained, with the number of glycans differing by glycan used too. ${ }^{20}$ Third, the temperature instability of many proteinbased LFDs above $30-40{ }^{\circ} \mathrm{C}$ may prevent devices from being deployed in various low-resource settings that lack established health infrastructures and cold chains. ${ }^{21,22}$ This is especially problematic, as more expensive lab-based diagnostic techniques are also not applicable, as exemplified by the COVID-19 crisis, creating a clear health inequality between higher- and lower-income countries. ${ }^{23}$

When considering test-line design, all test lines used in LFDs must be sufficiently hydrophobic to remain immobilized on the surface of the LFD as the mobile phase passes by, but must also be hydrophilic enough to dissolve in water for application to the stationary phase (many organic solvents can damage stationary phase materials). It is also common practice when designing LFDs to use a series of proteins or polymers such as bovine serum albumin, casein, or poly(vinylpyrrolidone) (PVP) as blocking agents (i.e., substances that coat ("block") the surface of the stationary phase, to prevent nonspecific binding of the mobile phase to the stationary phase). ${ }^{17,18}$ Blocking agents are either applied to the stationary phase as a pretreatment before the LFD is run or contained within the buffer of the LFD and run as a component of the mobile phase. PVP is an interesting case, as it is widely used in LFDs as a blocking agent, is hydrophilic enough to dissolve in water but hydrophobic enough to be immobilized onto nitrocellulose (reflected by vinylpyrrolidone's $\log \mathrm{P}$ of $\sim 0.37$ ), ${ }^{24}$ is widely used in biomedical applications, ${ }^{25}$ and is a synthetic polymer allowing for chemical modification. Therefore, it seemed an ideal candidate to prove the principle that a universal polymeric anchor for LFDs could be discovered.

Herein, we explore the use of capture-agent-functionalized PVP as a test line in flow-through assays, lateral flow assays, and lateral flow glycoassays, ${ }^{13}$ as the first example (to the best of our knowledge) of creating a synthetic polymer test line. The performance of the test line was investigated using biotinfunctionalized PVP with streptavidin-functionalized AuNPs (as the mobile phase) in a flow-through assay as well as free streptavidin and biotin-functionalized AuNPs in a lateral flow assay. Further exemplification is provided using glycosylated PVP to detect a lectin in a lateral flow glycoassay. Crucially, the polymer molecular weight can be tuned to impact the final output, providing a unique fine-tuning tool, not possible with current technologies. The polymer approach is also highly modular, as shown here. This new approach to immobilizing 
ligands onto the test line will help develop the next generation of LFDs and simplify workflows.

\section{RESULTS AND DISCUSSION}

The primary aim of this work was to synthesize and test the first generation of fully synthetic, protein-free test lines for use in LFD devices, to facilitate the development pipeline of new LFDs, using robust polymeric anchoring agents. Poly(vinylpyrrolidone), PVP, was chosen as the polymeric anchor, as it is widely used in LFDs as a blocking agent-it is flowed over the nitrocellulose stationary phase to reduce nonspecific interactions of analytes or media components. Hence, if it is blocking nonspecific binding, we reasoned that PVP must be sufficiently hydrophobic to interact/coat the nitrocellulose while also being hydrophilic enough to dissolve in water, ${ }^{26,27}$ which is an essential criterion for test-line printing from aqueous solution.

Reversible addition-fragmentation chain-transfer (RAFT) polymerization was employed, as it enables the synthesis of polymers with defined chain lengths and control over endgroups (crucial to add the binding ligand of interest). Furthermore, RAFT or MADIX (macromolecular design by the interchange of xanthates, a specific type of RAFT) is compatible with less-activated monomers (LAMs) such as NVP ( $N$-vinylpyrrolidone) or VAc (vinyl acetate), which are more challenging than, for example, (meth)acrylates to polymerize. $^{28-30}$ A xanthate chain-transfer agent (CTA) of 2-(ethoxycarbonothioylthio)-2-methylpropanoic acid N-hydroxysuccinimide ester was designed ${ }^{31}$ and synthesized with a N-hydroxysuccinimide (NHS) end-group that could be substituted by primary amines as shown in Figure $1 \mathrm{~A}$. Displacement of the NHS end-group could also be tracked using ${ }^{1} \mathrm{H}$ NMR analysis.

Three chain lengths of PVP telechelic homopolymers (DP = 50,80 , and 150) were synthesized (as determined by ${ }^{1} \mathrm{H}$ NMR end-group analysis) via thermally initiated RAFT polymerization using 4,4'-azobis (4-cyanovaleric acid) (ACVA) as a radical initiator (Figure 1B). Due to low conversions, which are typically observed in the polymer synthesis of LAMs, ${ }^{32}$ monomer to CTA ratios were higher than the target DPs $([\mathrm{M}]:[\mathrm{CTA}]=200,300$, and 500$)$ of 50, 80, and 150, respectively. Polymerization was also stopped at less than $100 \%$ conversion to maximize the retention of end-groups. Size exclusion chromatography (SEC) analysis in DMF with $5 \mathrm{mM}$ $\mathrm{NH}_{4} \mathrm{BF}_{4}$ revealed monomodal molecular weight distribution peaks with relatively low dispersities $\left(\bigoplus_{M} \leq 1.7\right.$ ) (Figure $1 \mathrm{C}$ and Table 1).

Table 1. PVP Polymers Prepared for the Detection of Streptavidin

\begin{tabular}{|c|c|c|c|c|c|}
\hline polymer & $\begin{array}{l}{[\mathrm{M}]:} \\
{[\mathrm{CTA}]}\end{array}$ & $\underset{\left.\mathrm{mol}^{-1}\right)}{\left.M_{\text {(target }}\right)} a^{(\mathrm{g}}$ & $\underset{\left.\mathrm{mol}^{-1}\right)^{b}}{M_{\mathrm{S}}}(\mathrm{g}$ & $\underset{\left.\mathrm{mol}^{-1}\right)}{M_{\mathrm{n}(\mathrm{NMR})}}(\mathrm{g}$ & $\bigoplus_{M}^{b}$ \\
\hline $\mathrm{PVP}_{50}$ & 200 & 22500 & 4500 & 5900 & 1.33 \\
\hline $\mathrm{PVP}_{80}$ & 300 & 33600 & 6000 & 9200 & 1.47 \\
\hline $\mathrm{PVP}_{150}$ & 500 & 55900 & 15100 & 17000 & 1.72 \\
\hline
\end{tabular}

${ }^{a}$ Determined from the feed ratio of the monomer to chain-transfer agent assuming $100 \%$ conversion. ${ }^{b}$ Calculated against poly(methyl methacrylate) standards using $5 \mathrm{mM} \mathrm{NH}_{4} \mathrm{BF}_{4}$ in DMF as an eluent. ${ }^{c}$ Determined from ${ }^{1} \mathrm{H}$ NMR end-group analysis by comparing the integrations of the $-\mathrm{CH}_{2}$ signals $(\delta 2.8 \mathrm{ppm})$ of the NHS end-group with those of the corresponding signals of the polymer.
To determine if PVP provided a suitable anchor, a model flow-through system was devised using a biotin-end-group, which has well-characterized and strong binding to streptavidin to test the capture principle. [Note, flow-through is distinct from full lateral flow, which has analyte and functionalized gold particles in the mobile phase, which is evaluated in full later.] An amino-biotin derivative was synthesized in three steps from ethylenediamine and biotin following procedures from Eisenführ et al. ${ }^{33}$ and Kaufman et al. (Figure 2A). ${ }^{34} \mathrm{~A}$ mono-t-Boc-protected diamine was synthesized ( $N$-Boc-ethylenediamine) and conjugated with biotin. The Boc protecting group was then removed using TFA to produce "biotin- $\mathrm{NH}_{2}$ ", a biotin derivative with amine functionality. ${ }^{34}$ The biotin- $\mathrm{NH}_{2}$ was characterized by ${ }^{1} \mathrm{H}$ and ${ }^{13} \mathrm{C}$ NMR, FTIR, and ESI mass spectrometry (Supporting Information). Functionalization of the PVP polymers (Figure 2B) was confirmed by the loss of the NHS protons in the ${ }^{1} \mathrm{H}$ NMR spectra and the addition of biotin- $\mathrm{NH}_{2}$ protons.

The biotin-functionalized PVP and an unfunctionalized PVP control were deposited onto the nitrocellulose dipsticks as test lines, in triplicate, of varying concentrations in water $(20,10$, and $1 \mathrm{mg} \cdot \mathrm{mL}^{-1}$ ) and then dried at $37^{\circ} \mathrm{C}$. It is noteworthy that all dipsticks run in this work were run in triplicate, image analyzed, and the average (mean) taken. A (commercial) gold nanoparticle (AuNP, $40 \mathrm{~nm}$ ) functionalized with streptavidin was flowed down the surface of the dipstick to determine if the biotin-functionalized PVP sequestered the streptavidin-functionalized particles. As a negative mobile phase, a previously reported galactosamine-functionalized poly(hydroxyethyl acrylamide) ( PHEA $_{72}$ ) gold nanoparticle (16 nm) system (Gal-PHEA ( $_{22} \mathrm{AuNP}_{16}$ ) was used, which has no affinity to biotin (Figure 3). ${ }^{13}$

All dipsticks that used a test line of biotin-functionalized PVPs successfully bound the streptavidin AuNPs at all concentrations of the applied test line. Example dipsticks and the surface image analysis are provided in Figure 4A. Images of all dipsticks and analysis are provided in the Supporting Information (Tables S4-S6 and Figures S23-S25). No nonspecific binding was observed to any of the triplicate controls at $20 \mathrm{mg} \cdot \mathrm{mL}^{-1}$ (except perhaps weak binding in one $\mathrm{PVP}_{50}$ test strip to the streptavidin-AuNP 40 ), although a "bleeding" effect (smearing of the test spot) was observed at higher test-line concentrations $\left(10\right.$ and $\left.20 \mathrm{mg} \cdot \mathrm{mL}^{-1}\right)$, indicating that the test-line concentration impacts binding and likely saturates the nitrocellulose membrane (Figure 4B). Interestingly the best polymer system, i.e., the system that provided the highest signal response, varied by concentration of test line applied, although all gave a positive signal in all triplicates run, with no observable off-target binding to the unfunctionalized PVP test line seen in the 10 or $1 \mathrm{mg} \cdot \mathrm{mL}^{-1}$ triplicates. This was first determined visually and then measured by digitally analyzing the image (Figure 4A) and signal-to-noise ratios determined (Figure $4 \mathrm{C}$ ). The $\mathrm{PVP}_{80}-$ biotin system had the highest signal response at $10 \mathrm{mg} \cdot \mathrm{mL}^{-1}$ but the lowest at $20 \mathrm{mg} \cdot \mathrm{mL}^{-1}$, while the $\mathrm{PVP}_{50}$-biotin system had the highest response at just $1 \mathrm{mg} \cdot \mathrm{mL}^{-1}$, while $\mathrm{PVP}_{80}-$ biotin and $\mathrm{PVP}_{150}$-biotin were comparable. This indicates that the systems produced require tuning to find the correct test line and concentration for the application; this additional tunability gained from varying polymer chain length is another benefit of the polymeric system versus protein-based systems.

Following the successful demonstration of a flow-through system with biotin-functionalized PVPs as a test line, the next 

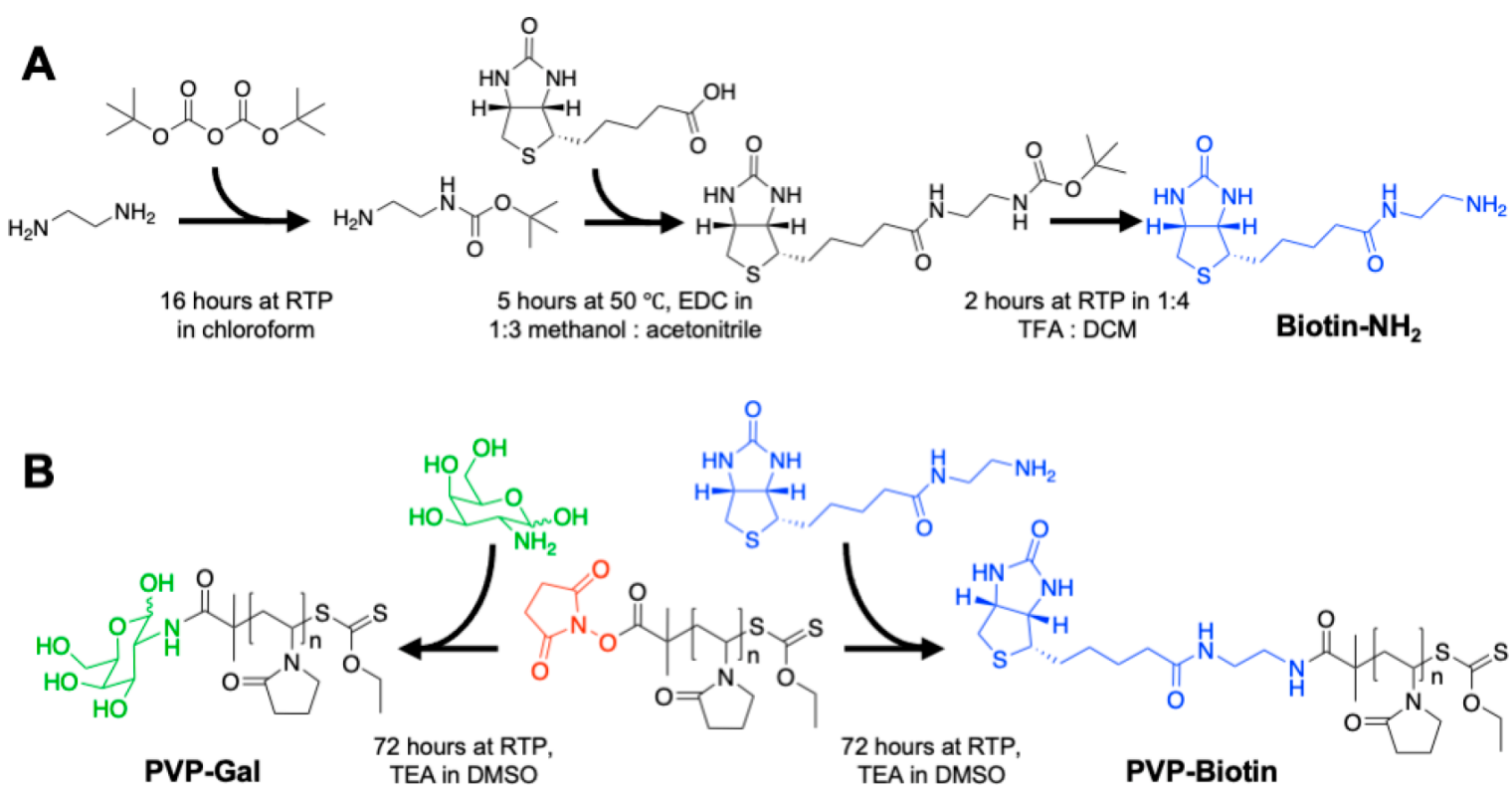

Figure 2. Synthesis of biotin-functionalized and galactosamine-functionalized PVP polymers. (A) Synthesis of biotin derivative; (B) synthesis of biotin-functionalized PVP polymers and galactosamine-functionalized PVP polymers.

step was to create a lateral flow setup that sensed for free streptavidin in solution, which requires biotin-functionalized AuNPs, coated with a noninteracting water-soluble polymer. Therefore, a series of biotin-functionalized poly $(N$-hydroxyethyl acrylamide)s (PHEA) were synthesized and immobilized on 16 and $40 \mathrm{~nm}$ gold nanoparticles (Figure 5A,B). PHEA was chosen because of its colloidal stability, ${ }^{35-37}$ solubility, and its established use to functionalize gold nanoparticles for lateral flow and flow-through devices. ${ }^{13}$ Using a pentafluorophenyl-2-dodecylthiocarbonothioylthio)-2methylpropanoate (PFP-DMP) chain-transfer agent (CTA) (see Supporting Information for a detailed synthetic procedure), a series of PHEA homopolymers were prepared $(\mathrm{DP}=53,72,110$, as determined by SEC, Figure 5C and Table 2) according to a previously described protocol. ${ }^{13}$ Biotin installation as the end-groups of PHEA homopolymers was achieved by the reaction of the pentafluorophenol (PFP) endgroup at the $\alpha$-terminus with biotin- $\mathrm{NH}_{2}$. The functionalized polymers were characterized by ${ }^{1} \mathrm{H}$ and ${ }^{19} \mathrm{~F}$ NMR and FTIR with successful conjugation of biotin- $\mathrm{NH}_{2}$ confirmed by loss of the PFP fluorine peaks in ${ }^{19} \mathrm{~F}$ NMR. The gold nanoparticles produced were characterized by UV-vis, DLS (Supporting Information Figures S13-S22 and Table S3), and X-ray photoelectron spectroscopy (XPS) (Figure 5D and Supporting Information Figures S35-S43 and Tables S20 and S21). The increase in the $\mathrm{N} \mathrm{1s} / \mathrm{C} 1 \mathrm{~s}$ ratios in the XPS spectra for the polymer-coated particles and the increased presence of amine and amide in the $\mathrm{C} 1 \mathrm{~s}$ spectra compared to the citratestabilized ("naked") nanoparticles confirmed the presence of polymers on the nanoparticles, alongside a shift in the UV-vis spectra. The library-based design approach to synthesizing AuNP systems for lateral flow and flow-through assays has been established by Baker et al. $^{13}$ as a method to find the appropriately sized polymer-coated gold particle for the intended diagnostic application.

The DLS (dynamic light scattering) analysis of the biotinfunctionalized $16 \mathrm{~nm}$ gold particles indicated some aggregation at all polymer lengths. This was observed in the dipsticks, run in triplicate, where the particles aggregated at the solvent front and on the PVP test lines even when no analyte and off-target protein (UEA, Ulex europaeus agglutinin I) at $0.05 \mathrm{mg} \cdot \mathrm{mL}^{-1}$ was present (Supporting Information Tables S7-S9). However, greater aggregation at the solvent front was observed in systems containing streptavidin, indicating affinity toward streptavidin; this was observed visually by more intense coloration at the solvent front, decreased background along the strips, and decreased coloration in the wick-indicating that fewer AuNPs passed the solvent front. Note, a PVP test concentration of $10 \mathrm{mg} \cdot \mathrm{mL}^{-1}$ was chosen to decrease the bleeding effect observed in the flow-through devices.

The biotin-PHEA-functionalized $40 \mathrm{~nm}$ gold particles were more stable in solution than the $16 \mathrm{~nm}$ particles. However, aggregation at the solvent front and with streptavidin at the solvent front was observed in the biotin-PHEA $72 @ \mathrm{AuNP}_{40}$ system but less so in the biotin-PHEA ${ }_{110} @ \mathrm{AuNP}_{40}$ system (Supporting Information Tables S10-12 and Figures S2628). Furthermore, off-target binding to the $10 \mathrm{mg} \cdot \mathrm{mL}^{-1} \mathrm{PVP}-$ biotin test lines was observed in all biotin-PHEA ${ }_{110} @ \mathrm{AuNP}_{40}$ systems. Hence, the concentration of the test line was decreased to $1 \mathrm{mg} \cdot \mathrm{mL}^{-1}$. At this concentration, the biotin$\mathrm{PHEA}_{110} @ \mathrm{AuNP}_{40}$ system bound to streptavidin at a protein concentration of $0.05 \mathrm{mg} \cdot \mathrm{mL}^{-1}$, and this AuNP-analyte complex was successfully bound by the $\mathrm{PVP}_{150}$-biotin test line (in all triplicates) with minimal nonspecific binding observed in the UEA or no analyte system (Figures 6 and 7, Supporting Information Table 3 and Figure S29). Notably, aggregation of the AuNP system with streptavidin was observed at the solvent front likely reducing signal and leading to increased background in the controls. This experiment confirmed that functionalized PVP test lines could be used successfully in LFDs.

To confirm it is the biotin that the streptavidin specifically binds in the test lines; streptavidin at $0.05 \mathrm{mg} \cdot \mathrm{mL}^{-1}$ with biotin-PHEA ${ }_{110} @ \mathrm{AuNP}_{40}$ particles was tested against biotinfunctionalized and unfunctionalized PVP test lines at a test-line concentration of $1 \mathrm{mg} \cdot \mathrm{mL}^{-1}$ (Supporting Information Table S14 and S30). While weak binding was observed to the unfunctionalized $\mathrm{PVP}_{50}$ test line, binding was far stronger to 

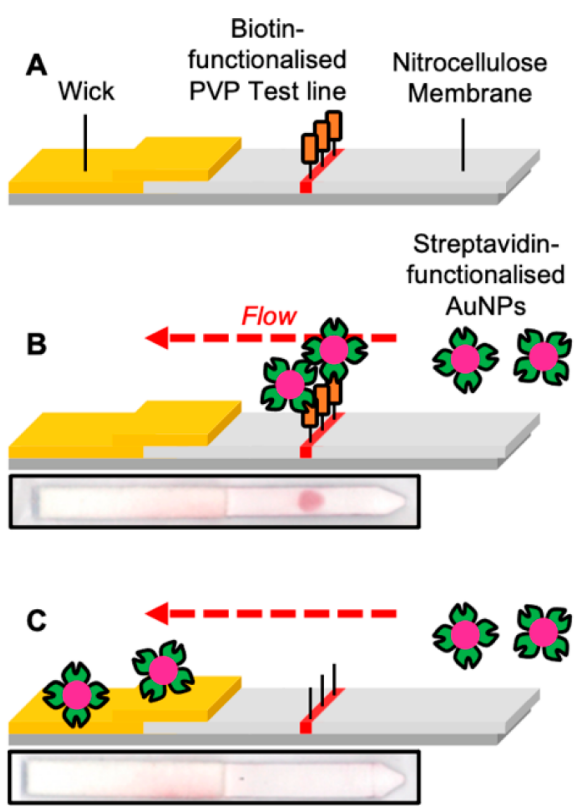

Galactosaminefunctionalised AuNPs
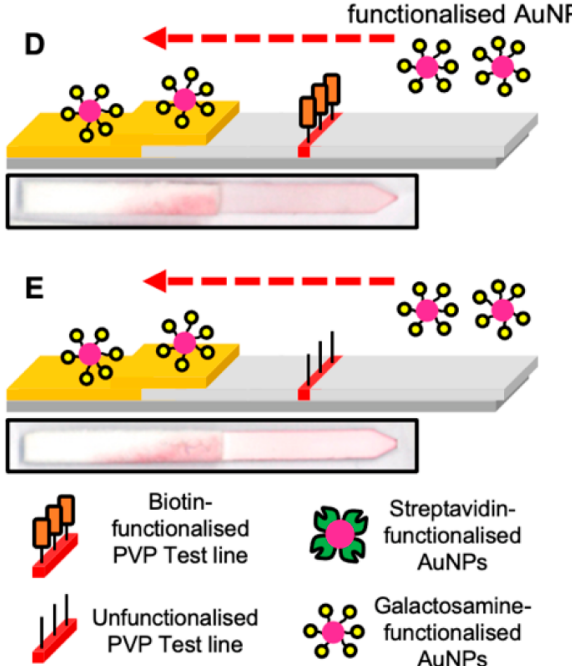

Figure 3. Schematic of dipstick flow-through assay and example dipsticks. (A) Design of dipstick; (B) flow-through with biotinfunctionalized PVP test line where streptavidin-functionalized AuNPs flow and engage the test line, resulting in signal generation; C) flowthrough with unfunctionalized PVP test line where streptavidinfunctionalized AuNPs flow and do not engage the test line, resulting in no signal generation; (D) flow-through with biotin-functionalized PVP test line where Gal-functionalized AuNPs flow and do not engage the test line, resulting in no signal generation; (E) flowthrough with unfunctionalized PVP test line where Gal-functionalized AuNPs flow and do not engage the test line, resulting in no signal generation.

the $\mathrm{PVP}_{50}$-biotin test line and all other biotin-functionalized test lines versus their unfunctionalized equivalents, with no binding to the unfunctionalized $\mathrm{PVP}_{150}$ test line observed in any of the triplicates. It is notable that signal intensity decreased with PVP chain length-likely because relative biotin concentration on the test line decreases as polymer chain length increases (as test-line concentration is measured by mass not molarity), although the decrease in off-target binding to unfunctionalized $\mathrm{PVP}_{150}$ led to a high signal-tonoise ratio for the $\mathrm{PVP}_{150}$-biotin system (Figure $7 \mathrm{~B}$ ). Attempts to use a lower concentration of streptavidin (0.005

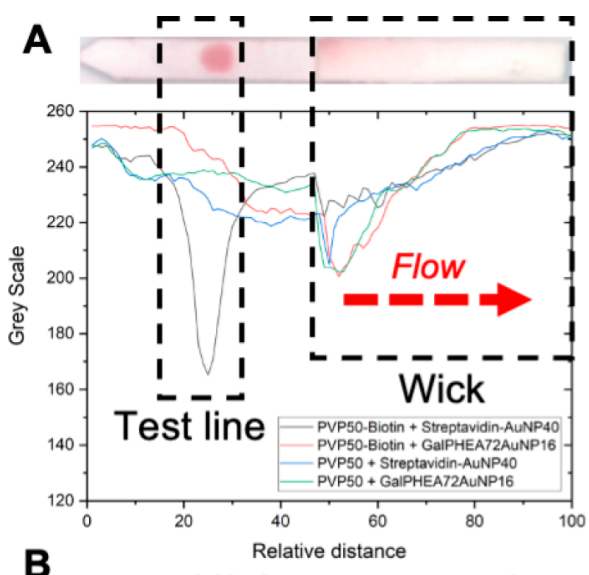

B

High concentration

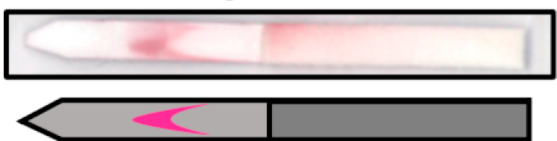

Lower concentration
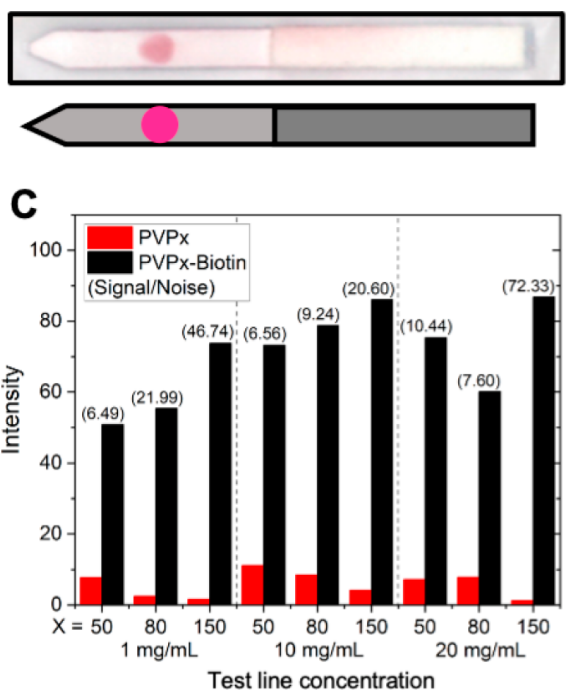

Figure 4. Analysis of flow-through dipstick assays. (A) Analysis of $\mathrm{PVP}_{50}$-biotin and unfunctionalized $\mathrm{PVP}_{50}\left(1 \mathrm{mg} \cdot \mathrm{mL}^{-1}\right)$ versus streptavidin-functionalized AuNPs and galactosamine-functionalized AuNPs, with example dipstick of $\mathrm{PVP}_{50}$-biotin versus streptavidin$\mathrm{AuNP}_{40}$; (B) representative example dipsticks and graphical representation of test-line "bleeding" effect at high (top, $20 \mathrm{mg}$. $\mathrm{mL}^{-1}$ ) and lower test-line concentrations (bottom, $\left.1 \mathrm{mg} \cdot \mathrm{mL}^{-1}\right)$; (C) intensity of $\mathrm{PVP}_{x}$ and $\mathrm{PVP}_{x}$ - biotin at varying concentrations versus streptavidin-functionalized $\mathrm{AuNP}_{40}$ (signal-to-noise ratio $\left(\mathrm{PVP}_{x}-\right.$ biotin intensity/ $\mathrm{PVP}_{x}$ intensity) is provided in brackets).

$\mathrm{mg} \cdot \mathrm{mL}^{-1}$ ) and the $\mathrm{PVP}_{150}$-biotin test line were unsuccessful, with a signal-to-noise ratio of $\sim 1$. However, binding to the $\mathrm{PVP}_{80}$-biotin was observed at this concentration $(0.005 \mathrm{mg}$. $\mathrm{mL}^{-1}$ streptavidin) versus unfunctionalized $\mathrm{PVP}_{80}$ (signal-tonoise ratio of $>7$ ), likely due to decreased aggregation at the solvent front between the particles and streptavidin (Figure 7B, Supporting Information Tables S15 and S31), indicating the need to tune the AuNP system for the target analyte and test line used in a finished device.

In comparison to antibody-based lateral flow immunoassays that often have limits of detection ranging from micrograms to nanograms per milliliter, ${ }^{38}$ this system when targeting streptavidin has a limit of detection (LOD) of $\sim 0.05-0.005$ 

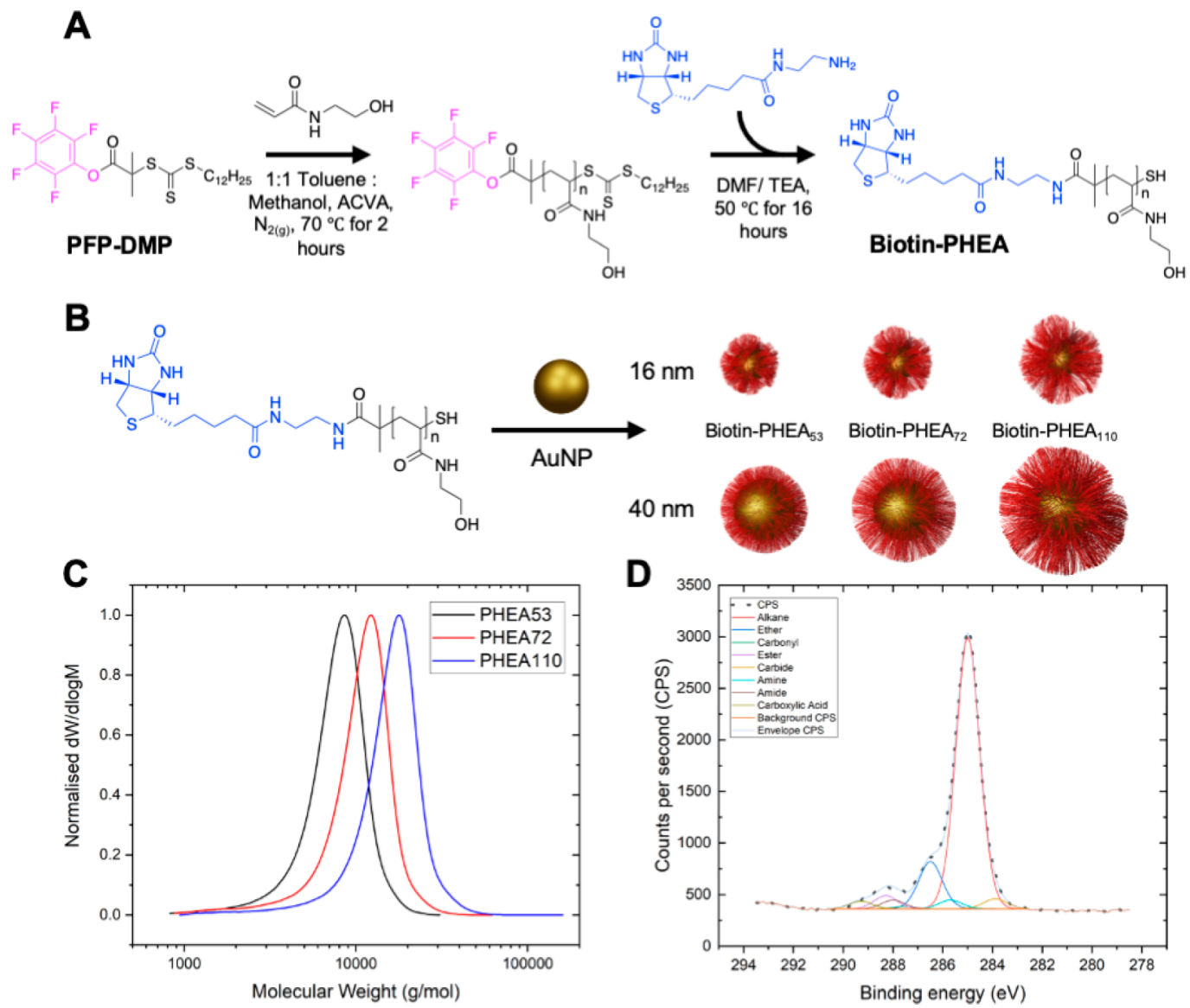

Figure 5. Synthesis of PHEA polymers and AuNPs. (A) Polymerization of $N$-hydroxyethyl acrylamide (HEA) and postfunctionalization with a biotin derivative; (B) synthesis of polymer-functionalized AuNPs; (C) normalized size exclusion chromatography analysis of PHEA polymers from Table 2; (D) C 1s XPS scan of biotin-PHEA $72 @ \mathrm{AuNP}_{40}$.

Table 2. PHEA Polymers Prepared for the Detection of Streptavidin

\begin{tabular}{|c|c|c|c|c|c|}
\hline polymer & $\begin{array}{c}{[\mathrm{M}]:} \\
{[\mathrm{CTA}]}\end{array}$ & 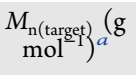 & $\underset{\mathrm{mol}^{\mathrm{n}(\mathrm{SEC})}}{\left.\mathrm{mol}^{-1}\right)^{b}}(\mathrm{~g}$ & $\underset{\left.\mathrm{mol}^{-1}\right)_{c}}{M_{\mathrm{n}(\mathrm{NMR}}} c(\mathrm{~g}$ & $\bigoplus_{M}^{b}$ \\
\hline PHEA $_{53}$ & 28 & 3800 & 6600 & 6000 & 1.24 \\
\hline $\mathrm{PHEA}_{72}$ & 40 & 5100 & 8900 & 8600 & 1.28 \\
\hline $\mathrm{PHEA}_{110}$ & 70 & 8600 & 13000 & 14000 & 1.27 \\
\hline
\end{tabular}

${ }^{a}$ Determined from the feed ratio of the monomer to chain-transfer agent. ${ }^{b}$ Calculated against poly(methyl methacrylate) standards using $5 \mathrm{mM} \mathrm{NH}_{4} \mathrm{BF}_{4}$ in DMF as an eluent. ${ }^{c}$ Determined from ${ }^{1} \mathrm{H} \mathrm{NMR}$ end-group analysis by comparing the integrations of the $-\mathrm{CH}_{3}$ signals ( $\delta 0.92 \mathrm{ppm}$ ) of the dodecyl end-group with those of the corresponding signals of the polymer.

$\mathrm{mg} \cdot \mathrm{mL}^{-1}$ or $\sim 0.8-0.08 \mathrm{nmol} \cdot \mathrm{mL}^{-1}$ for the $\mathrm{PVP}_{150}-$ biotin and $\mathrm{PVP}_{80}$-biotin systems. This is higher than many commercially available lateral flow immunoassays but is comparable to commercial pregnancy test LFDs with molar LODs of $\sim 0.7-$ $0.07 \mathrm{nmol} \cdot \mathrm{mL}^{-1}$. 39

While biotin-streptavidin is an excellent model system, its low $K_{\mathrm{d}}\left(\sim 10^{-14} \mathrm{~mol} \cdot \mathrm{dm}^{-3}\right)^{40}$ is not representative of many analyte-capture agent scenarios that have lower affinity (higher $\left.K_{\mathrm{d}}\right)$. Therefore, soybean agglutinin (SBA), a lectin with a known affinity for galactosamine, was chosen as an analyte. We have previously designed and validated an appropriate gold nanoparticle system ( $\left.\mathrm{Gal}-\mathrm{PHEA}_{72} @ \mathrm{AuNP}_{16}\right)$ to sense specifically for SBA in an LFD device using protein agents to immobilize the glycan to the stationary phase. ${ }^{13}$ It was anticipated that the PVP test lines functionalized with galactosamine may not perform as well as their glycan-BSA counterpart ( $\mathrm{Gal} \alpha 1-3 \mathrm{Gal} \beta 1-4 \mathrm{GlcNAc}-\mathrm{BSA})$. This is likely due to the loss of the cluster glycoside effect (the glycan-BSA used carried $>20$ glycans per BSA protein as reported by the manufacturer) and the use of galactosamine (with free anomeric position) as the binding glycan in the PVP system. Initial attempts, in triplicate, to use $20 \mathrm{mg} \cdot \mathrm{mL}^{-1}$ galactosamine-functionalized PVPs and an SBA concentration in solution of $0.05 \mathrm{mg} \cdot \mathrm{mL}^{-1}$ proved unsuccessful with no binding observed to the SBA (Supporting Information Table S16). However, no off-target binding was observed to either the nolectin, UEA, or unfunctionalized PVP systems (in any test), which was promising. A higher concentration of SBA $(0.5 \mathrm{mg}$. $\mathrm{mL}^{-1}$ ) was therefore chosen for the lateral flow glycoassay (Supporting Information Table S17 and Figure S32). While this concentration of SBA did lead to nonspecific binding of the SBA-particle complex to the unfunctionalized PVP test line in all cases and in all triplicates; stronger signals were observed in the $\mathrm{PVP}_{150}-\mathrm{Gal}$ system (Figure 8), with the $\mathrm{PVP}_{150}-\mathrm{Gal}$ system (signal) versus the unfunctionalized $\mathrm{PVP}_{150}$ system (noise) having a signal-to-noise ratio of 2.44 (Figure 8C). This indicates that the limit of detection (LOD) of SBA is between $\sim 0.5-0.05 \mathrm{mg} \cdot \mathrm{mL}^{-1}$. This compares well to a system using the same nanoparticles in a setup against a test line of $\mathrm{Gal} \alpha 1-3 \mathrm{Gal} \beta 1-4 \mathrm{GlcNAc}-\mathrm{BSA}\left(1 \mathrm{mg} \cdot \mathrm{mL}^{-1}\right)$, with an LOD of $\sim 0.02 \mathrm{mg} \cdot \mathrm{mL}^{-1} .^{41}$ Considering the PVP does not (likely) benefit from the cluster glycoside effect to the same 


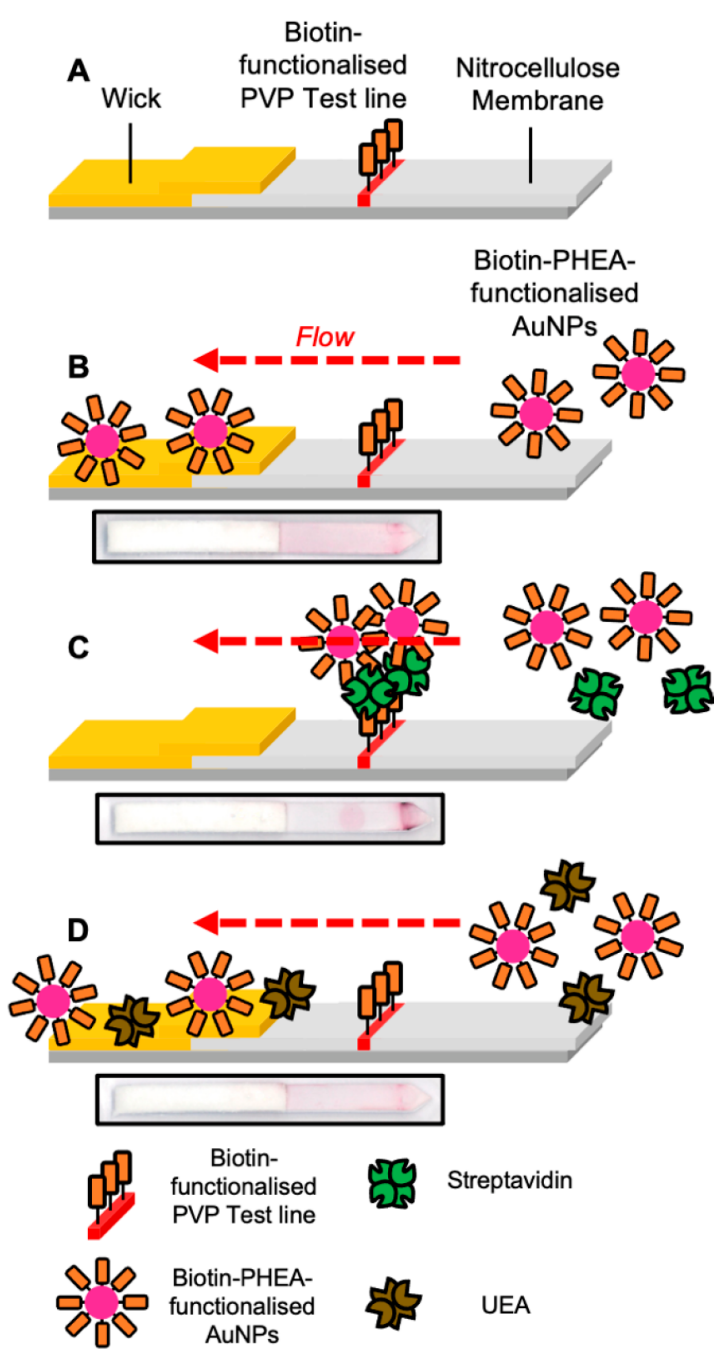

Figure 6. Schematic of dipstick lateral flow assay and example dipsticks. (A) Design of dipstick; (B) lateral flow with biotinfunctionalized PVP test line with no analyte in solution, and biotinPHEA-functionalized AuNPs flow and do not engage the test line, resulting in no signal generation; (C) lateral flow with biotinfunctionalized PVP test line with streptavidin $\left(0.05 \mathrm{mg} \cdot \mathrm{mL}^{-1}\right)$ in solution, and biotin-functionalized AuNPs flow and do engage the test line, resulting in signal generation; (D) lateral flow with biotinfunctionalized PVP test line with UEA $\left(0.05 \mathrm{mg} \cdot \mathrm{mL}^{-1}\right)$ in solution, and biotin-functionalized AuNPs flow and do engage the test line, resulting in no signal generation.

extent as a multivalent protein surface, ${ }^{42}$ the LOD achieved is promising. Although, it is possible that the lectins can bind multiple PVP chains, depending on their exact orientation on the surface. Notably, the PVP-based system is not as sensitive as antibody-based LFDs, such as those for ricin (LOD $\approx 20 \mathrm{ng}$. $\left.\mathrm{mL}^{-1}\right)^{43}$ or a concanavalin A $\left(\mathrm{LOD} \sim 0.1 \mu \mathrm{g} \cdot \mathrm{mL}^{-1}\right),{ }^{16}$ but it does indicate the potential for the integration of polymer systems into LFDs.

Decreasing the concentration of the PVP test-line systems was attempted but yielded mixed results (Supporting Information Tables S18 and 19 and Figures S33 and 34), indicating that the $20 \mathrm{mg} \cdot \mathrm{mL}^{-1} \mathrm{PVP}_{150}-\mathrm{Gal}$ system is the optimum for this particular particle system and analyte. Interestingly, this is different from the concentration used in the biotin-functionalized PVP lateral flow system and the optimum chain length in some of the flow-through assays. This
A

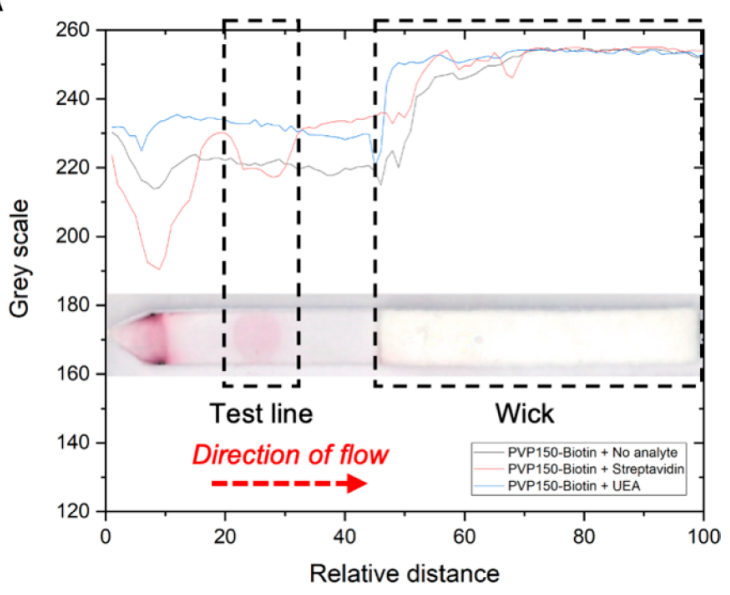

B

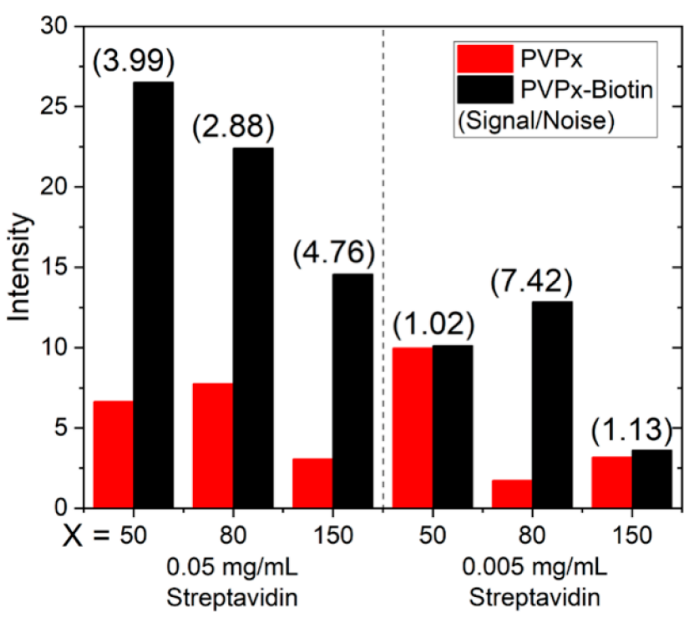

Figure 7. Analysis of scanned lateral flow strips using test lines of PVP $_{150}$-biotin. (A) $\mathrm{PVP}_{150}$-biotin $\left(1 \mathrm{mg} \cdot \mathrm{mL}^{-1}\right)$ versus either no analyte, streptavidin $\left(0.05 \mathrm{mg} \cdot \mathrm{mL}^{-1}\right)$, or UEA $\left(0.05 \mathrm{mg} \cdot \mathrm{mL}^{-1}\right)$ used with biotin-PHEA $110 \mathrm{AuNP}_{40}$ (inset example dipstick from $\mathrm{PVP}_{150}$-biotin versus streptavidin); (B) intensity of $\mathrm{PVP}_{x}(1 \mathrm{mg}$. $\left.\mathrm{mL}^{-1}\right)$ and $\mathrm{PVP}_{x}$-biotin $\left(1 \mathrm{mg} \cdot \mathrm{mL}^{-1}\right)$ versus streptavidin of varying concentrations using with biotin-PHEA $110 \mathrm{AuNP}_{40}$ (signal-to-noise ratio $\left(\mathrm{PVP}_{x}\right.$-biotin intensity/ $\mathrm{PVP}_{x}$ intensity) is provided in brackets).

indicates the need to tune each system depending on the application, again highlighting the tunability benefits of polymer chemistry over protein-based systems. Furthermore, the background could be improved by adjusting the buffer, tuning the AuNP system, or treating the membrane. Meanwhile, the signal could be improved by printing the test line, rather than using "by hand" deposition of a test spot or using a more complex glycan with greater affinity for SBA. These sorts of modifications were however beyond the scope of this work that focuses on a proof of concept for polymeric test lines.

\section{CONCLUSIONS}

Here, the concept of a fully synthetic, protein-free, polymeric lateral flow test-line is validated and explored for the first time. It is shown to be a promising alternative to the established protein-based anchoring reagents. Poly(vinylpyrrolidone), PVP, was identified as promising immobilization agent, based on its widespread use as a "blocking agent", which is sufficiently hydrophobic to adhere to nitrocellulose stationary phases but still being water-soluble, which is essential for 


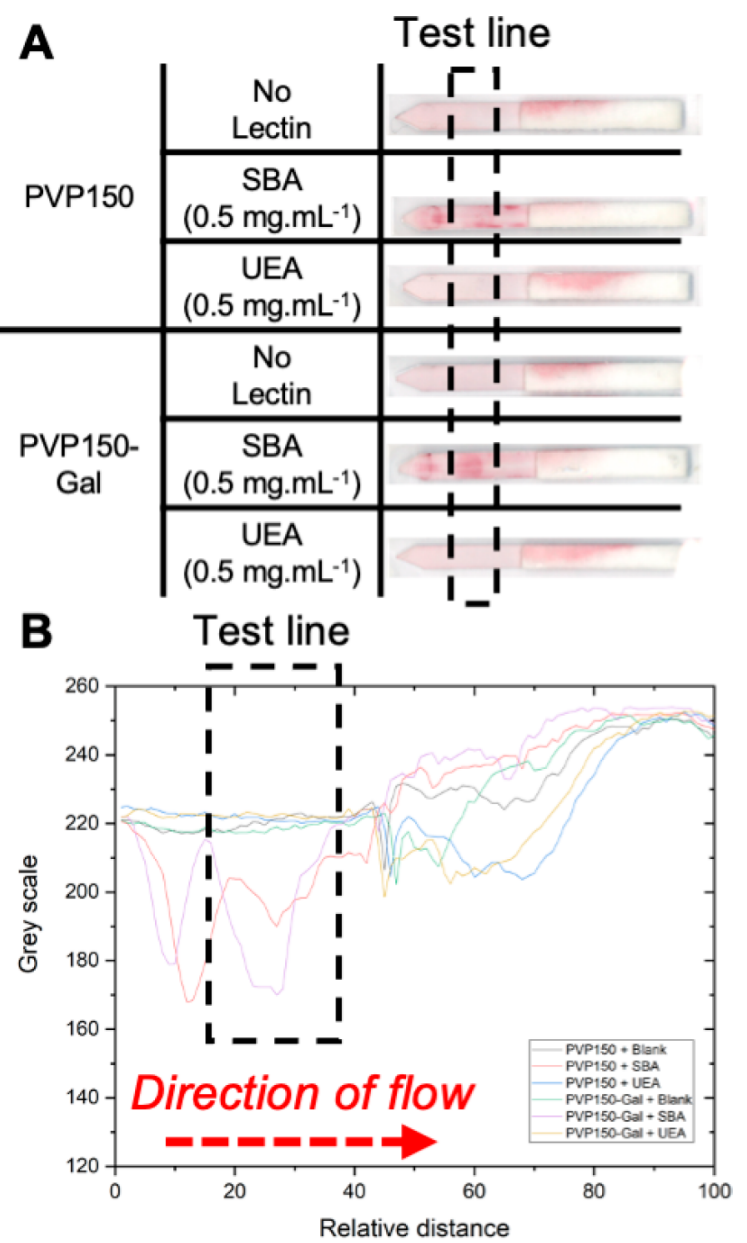

C

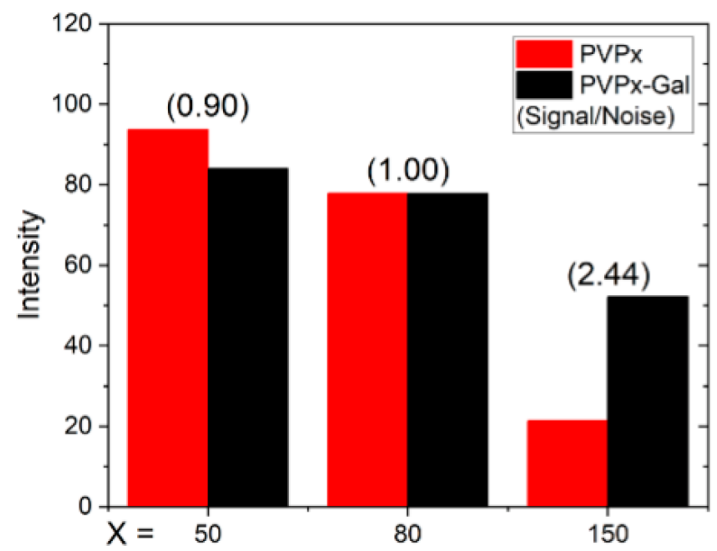

Figure 8. Lateral flow strips and analysis using test lines of $\mathrm{PVP}_{150}-$ $\mathrm{Gal}$ and $\mathrm{PVP}_{150}\left(20 \mathrm{mg} \cdot \mathrm{mL}^{-1}\right)$. (A) Example lateral flow strips using test lines of $\mathrm{PVP}_{150}-\mathrm{Gal}$ and $\mathrm{PVP}_{150}\left(20 \mathrm{mg} \cdot \mathrm{mL}^{-1}\right)$ versus no analyte, SBA $\left(0.5 \mathrm{mg} \cdot \mathrm{mL}^{-1}\right)$, and UEA $\left(0.5 \mathrm{mg} \cdot \mathrm{mL}^{-1}\right)$, using Gal-PHEA ${ }_{72} @$ $\mathrm{AuNP}_{16} ;(\mathrm{B})$ analysis of scanned lateral flow strips using test lines of $\mathrm{PVP}_{150}-\mathrm{Gal}$ and $\mathrm{PVP}_{150}\left(20 \mathrm{mg} \cdot \mathrm{mL}^{-1}\right)$ versus either no analyte, SBA $\left(0.5 \mathrm{mg} \cdot \mathrm{mL}^{-1}\right)$, and UEA $\left(0.5 \mathrm{mg} \cdot \mathrm{mL}^{-1}\right)$; (C) intensity of $\mathrm{PVP}_{x}(20$ $\left.\mathrm{mg} \cdot \mathrm{mL}^{-1}\right)$ and $\mathrm{PVP}_{x}-\mathrm{Gal}\left(20 \mathrm{mg} \cdot \mathrm{mL}^{-1}\right)$ versus SBA $\left(0.5 \mathrm{mg} \cdot \mathrm{mL}^{-1}\right)$ (signal-to-noise ratio $\left(\mathrm{PVP}_{x}-\mathrm{Gal}\right.$ intensity/ $\mathrm{PVP}_{x}$ intensity) is provided in brackets).

production/printing of the test line. PVP was synthesized by RAFT/MADIX polymerization using an $N$-hydroxy-succinimide (NHS)-functionalized chain-transfer agent, which allowed subsequent installation of a glycan or biotin, as a capture ligand. The polymer anchor was shown to allow capture in flow-through and lateral flow systems, leading to specific binding with limited off-target (nonspecific) binding. A key observation was that the chain length of the PVP (as well as the concentration applied) was crucial to optimize the signal generation and specificity. For example, in the flow-through system when targeting streptavidin-functionalized particles in the mobile phase, the best PVP-biotin chain length varied with the concentration of the test line used. Meanwhile, in the lateral flow system when targeting streptavidin, a $1 \mathrm{mg} \cdot \mathrm{mL}^{-1}$ test line of $\mathrm{PVP}_{150}$-biotin was best, and in the lateral flow glycoassay, when targeting SBA, a $20 \mathrm{mg} \cdot \mathrm{mL}^{-1} \mathrm{PVP}_{150}-\mathrm{Gal}$ test line was best.

We anticipate that the polymeric system discussed (PVP) could be used as a multifunctional scaffold or platform to present other capture agents such as short amino acid or nucleotide sequences and enable a wider range of end-group functionality beyond amide chemistry (i.e., click chemistry approaches). The ability to tune the molecular weight of a polymeric test line will allow further fine-tuning, in contrast to protein-based anchors. Furthermore, the addition of multivalency to the system could also be explored while maintaining synthetic control over the number of capture agents per polymer anchor unit. Plus, there exists many thousands of potential (co)polymer structures, which provide further opportunities to refine the polymer test-line approach. In summary, the PVP scaffolds presented and validated here provide the first examples of a tunable and multifunctional polymeric test-line capture system for lateral flow devices and further epitomize the potential of applying polymer chemistry to LFDs.

\section{EXPERIMENTAL SECTION}

\section{Materials}

All chemicals were used as supplied unless otherwise stated. $\mathrm{N}$ Hydroxyethyl acrylamide (97\%), 4,4'-azobis(4-cyanovaleric acid) (ACVA, 98\%), 4-(dimethylamino)pyridine (DMAP, >98\%), mesitylene (reagent grade), triethylamine (TEA, >99\%), sodium citrate tribasic dihydrate ( $>99 \%)$, gold(III) chloride trihydrate $(99.9 \%)$, potassium phosphate tri basic $\left(\geq 98 \%\right.$, reagent grade), $N, N^{\prime}$ diisopropylcarbodiimide (DIC, 99\%), 1-vinyl-2-pyrrolidone ( $\geq 98.0 \%$ for synthesis), DMSO (ACS reagent, $\geq 99.9 \%$ ), deuterated DMSO (DMSO- $\left.d_{6}, \geq 99 \%\right)$, deuterium oxide $\left(\mathrm{D}_{2} \mathrm{O}, 99.9 \%\right)$, deuterated chloroform $\left(\mathrm{CDCl}_{3}, 99.8 \%\right)$, deuterated methanol $\left(\mathrm{CD}_{3} \mathrm{OD}\right.$, ( $\geq 99.8 \%)$, diethyl ether ( $\geq 99.8 \%$, ACS reagent grade), methanol ( $\geq 99.8 \%$, ACS reagent grade), toluene $(\geq 99.7 \%$,), di-tert-butyl dicarbonate $(\geq 98.0 \%)$, Tween-20 (molecular biology grade), HEPES, PVP40 (poly(vinylpyrrolidone) ${ }_{400}$ (average $M_{\mathrm{w}} \approx 40000$ ), carbon disulfide $(\geq 99.8 \%)$, acetone ( $\geq 99 \%)$, 1-dodecanethiol ( $\geq 98 \%$ ), biotin ( $\geq 99 \%$, HPLC lyophilized powder), $40 \mathrm{~nm}$ gold nanoparticles (OD1 in citrate buffer), streptavidin-gold (40 nm) from Streptomyces avidinii, pentafluorophenol ( $\geq 99 \%$, reagent plus), $N$-hydroxysuccinimide (98\%), ethylenediamine ( $\geq 99.5 \%)$, ethyl acetate ( $\geq 99.5 \%$ ), trifluoroacetic acid (TFA, $\geq 99 \%$, reagent plus), sodium azide ( $\geq 99.5 \%$, reagent plus), and potassium permanganate $(\geq 99 \%)$ were purchased from Sigma-Aldrich. Potassium ethyl xanthate (98\%) was purchased from Alfa Aesar. DMF (>99\%) and 2-bromo-2-methyl-propionic acid (98\%) were purchased from Acros Organics. Galactosamine $\mathrm{HCl}$ and 1-ethyl-3-(3-(dimethylamino)propyl)carbodiimide hydrochloride (EDCI, $>98 \%$ ) were purchased from Carbosynth. Hexane fraction from petrol (lab reagent grade), DCM (99\% lab reagent grade), sodium hydrogen carbonate ( $\geq 99 \%)$, ethyl acetate ( $\geq 99.7 \%$, analytical reagent grade), sodium chloride $(\geq 99.5 \%)$, calcium chloride, $40-60$ petroleum ether (lab reagent grade), hydrochloric acid ( $\sim 37 \%$, analytical grade), glacial acetic acid 
(analytical grade) and magnesium sulfate (reagent grade), THF (HPLC), chloroform ( $\geq 99 \%)$, Molecular Sieve type $4 \AA$ nominal pore size (general purpose grade), and 1,4-dioxane ( $\geq 99 \%)$ were purchased from Thermo Fisher Scientific. Ethanol absolute was purchased from VWR International. Nitrocellulose Immunopore RP $90-150 \mathrm{~s} / 4 \mathrm{~cm} 25 \mathrm{~mm}$ was purchased from GE Healthcare. Lateral flow backing cards, 60 by $301.58 \mathrm{~mm}$ (KN-PS1060.45 with KN211 adhesive), were purchased from Kenosha Tapes. Cellulose fiber wick material, $20 \mathrm{~cm}$ by $30 \mathrm{~cm}$ by $0.825 \mathrm{~mm}(290 \mathrm{gsm}$ and $180 \mathrm{~mL} / \mathrm{min}$ ) (Surewick CFSP223000) was purchased from EMD Millipore. Soybean agglutinin and Ulex Europaeus Agglutinin I were purchased from Vector Laboratories. Spectra/Por 7 Dialysis Membrane Pretreated RC (regenerated cellulose) Tubing MWCO: $1 \mathrm{kDa}$ was purchased from Spectrum Laboratories. Streptavidin lyophilized was purchased from Stratech Scientific. Ultrapure water used for buffers was Milli-Q grade, $18.2 \mathrm{~m} \Omega \cdot \mathrm{cm}$ resistance.

\section{Synthetic Methods}

MADIX Agent Synthesis: 2-(Ethoxycarbonothioylthio)-2methylpropanoic Acid $\mathrm{N}$-Hydroxysuccinimide Ester (MADIX1). $10.27 \mathrm{~g}$ (61.50 mmol) of 2-bromo-2-methyl-propionic acid was dissolved in $60 \mathrm{~mL}$ of ethanol. $15.00 \mathrm{~g}(93.57 \mathrm{mmol})$ of potassium $O$-ethyl xanthate was added, and the mixture was stirred for $38 \mathrm{~h}$ at RTP. The reaction mixture was filtered under gravity, and the filtrate was diluted with $400 \mathrm{~mL}$ of diethyl ether. The organic layer was washed with water $(200 \mathrm{~mL} \times 3)$, and the aqueous layers were combined and acidified with $6 \mathrm{M} \mathrm{HCl}$. The aqueous layers were extracted with diethyl ether $(200 \mathrm{~mL} \times 3)$ and combined with all organic layers. The solution was dried with $\mathrm{MgSO}_{4}$ and filtered under gravity. The solvent was removed under vacuum to form a yellow oil.

$8.83 \mathrm{~g}$ (42.45 mmol) of crude product (2-((ethoxycarbonothioyl)thio)-2-methylpropanoic acid) and $9.50 \mathrm{~g}(82.54 \mathrm{mmol})$ of $\mathrm{N}$ hydroxysuccinimide were added to an empty $\mathrm{RBF}$ and purged with nitrogen before $40 \mathrm{~mL}$ of anhydrous THF was added; the solution was then degassed for a further $20 \mathrm{~min}$. The solution was cooled to 0 ${ }^{\circ} \mathrm{C}$, and $8 \mathrm{~mL}$ (9.93 g, $\left.78.65 \mathrm{mmol}\right)$ of $\mathrm{N}, \mathrm{N}$-diisopropyl carbodiimide was added dropwise over $10 \mathrm{~min}$. The flask was put under positive nitrogen pressure and stirred for $48 \mathrm{~h}$. The solution was filtered under gravity, and the filtrate solvent was removed under vacuum. The crude solid was dissolved in $100 \mathrm{~mL}$ of diethyl ether and $100 \mathrm{~mL}$ of saturated $\mathrm{NaHCO}_{3}$ solution. The organic layer was washed with water $(100 \mathrm{~mL} \times 3)$ and $100 \mathrm{~mL}$ of brine once. The organic layer was dried with $\mathrm{MgSO}_{4}$ and filtered under gravity. The solvent was then removed from the filtrate under vacuum. The crude product was recrystallized in ethyl acetate overnight at $-8{ }^{\circ} \mathrm{C}$, washed with cold hexane, and dried to give yellow crystals $(25.2 \%) . \delta_{\mathrm{H}}\left(300 \mathrm{MHz}, \mathrm{CDCl}_{3}\right) 4.69$ $\left(2 \mathrm{H}, \mathrm{q}, J 7.0, \mathrm{OCH}_{2}\right), 2.85-2.81\left(4 \mathrm{H}, \mathrm{m}, \mathrm{C}(\mathrm{O}) \mathrm{CH}_{2} \mathrm{CH}_{2} \mathrm{C}(\mathrm{O})\right), 1.76$ $\left(6 \mathrm{H}, \mathrm{s}, \mathrm{C}\left(\mathrm{CH}_{3}\right)_{2}\right), 1.37\left(3 \mathrm{H}, \mathrm{t}, J 7.0, \mathrm{CH}_{2} \mathrm{CH}_{3}\right) . \delta_{\mathrm{C}}(300 \mathrm{MHz}$, $\left.\mathrm{CDCl}_{3}\right) 208.92(1 \mathrm{C}, \mathrm{SC}(\mathrm{S}) \mathrm{S}), 171.43(1 \mathrm{C}, \mathrm{OC}(\mathrm{O})), 168.82(2 \mathrm{C}$, $\mathrm{NC}(\mathrm{O}), 71.00\left(1 \mathrm{C}, \mathrm{OCH}_{2}\right), 52.41\left(1 \mathrm{C}, \mathrm{C}\left(\mathrm{CH}_{3}\right)_{2}\right), 26.15(2 \mathrm{C}, \mathrm{C}(\mathrm{O})$ $\left.\mathrm{CH}_{2} \mathrm{CH}_{2} \mathrm{C}(\mathrm{O})\right), 25.73\left(2 \mathrm{C}, \mathrm{C}\left(\mathrm{CH}_{3}\right)_{2}\right), 13.07\left(1 \mathrm{C}, \mathrm{CH}_{2} \mathrm{CH}_{3}\right) . \mathrm{m} / z$ calculated as 305.36; found for ESI $[\mathrm{M}+\mathrm{Na}]^{+} 328.1$. FTIR $\left(\mathrm{cm}^{-1}\right)$ 2989.32 and 2940.46 (methyl or methylene), 1779.80 (ester carbonyl), 1731.34 (amide), 1462 (methyl), 1202.06 (C=S), 1038.06 (S-C(S)-O).

Representative Polymerization of $\mathrm{N}$-Vinylpyrrolidone (PVP80). $5.65 \mathrm{~mL}$ (5.43 g, $48.88 \mathrm{mmol}$ ) of $\mathrm{N}$-vinylpyrrolidone, $0.010 \mathrm{~g}(0.036 \mathrm{mmol})$ of ACVA, and $0.0523 \mathrm{~g}(0.171 \mathrm{mmol})$ of MADIX1 were added to $8.5 \mathrm{~mL}$ of dioxane and degassed with nitrogen for $20 \mathrm{~min}$. The reaction was stirred at $80{ }^{\circ} \mathrm{C}$ for 3 days. The solvent was removed under vacuum, and the solid was dialyzed using $0.5-1 \mathrm{kDa}$ cellulose ester tubing in water. The dialyzed product was freeze-dried overnight to give a white powder. $\delta_{\mathrm{H}}\left(300 \mathrm{MHz}, \mathrm{CDCl}_{3}\right)$ 4.06-3.48 (80H, m, NCH $\left.{ }_{2}\right), 3.47-2.98\left(184 \mathrm{H}, \mathrm{m}, \mathrm{NC}(\mathrm{O}) \mathrm{CH}_{2}\right)$ 2.85-2.77 (4H, m, C $\left.(\mathrm{O}) \mathrm{CH}_{2} \mathrm{CH}_{2} \mathrm{C}(\mathrm{O})\right), 2.58-2.13(253 \mathrm{H}, \mathrm{m}$, $\left.\mathrm{NC}(\mathrm{O}) \mathrm{CH}_{2}\right), 2.13-1.84\left(206 \mathrm{H}, \mathrm{m}, \mathrm{NCH}_{2} \mathrm{CH}_{2}\right), 1.84-1.03(204 \mathrm{H}$, $\left.\mathrm{m},\left(\mathrm{CH}_{3}\right)_{2} \& \mathrm{NCHCH}_{2} \& \mathrm{OCH}_{2} \mathrm{CH}_{3}\right)$. FTIR $\left(\mathrm{cm}^{-1}\right) 2926$ (alkyl stretch), 1655 (lactam amide), $1422\left(\mathrm{CH}_{2}\right)$.

PVP50 $\delta_{\mathrm{H}}\left(300 \mathrm{MHz}, \mathrm{CDCl}_{3}\right) 4.16-3.45\left(50 \mathrm{H}, \mathrm{m}, \mathrm{NCH}_{2}\right), 3.51-$ $2.96\left(100 \mathrm{H}, \mathrm{m}, \mathrm{NC}(\mathrm{O}) \mathrm{CH}_{2}\right)$ 2.86-2.74 $\left(4 \mathrm{H}, \mathrm{m}, \mathrm{C}(\mathrm{O}) \mathrm{CH}_{2} \mathrm{CH}_{2} \mathrm{C}-\right.$
(O)), 2.71-2.14 (129H, m, NC(O) $\left.\mathrm{CH}_{2}\right), 2.14-1.85(111 \mathrm{H}, \mathrm{m}$, $\left.\mathrm{NCH}_{2} \mathrm{CH}_{2}\right)$, 1.85-1.01 (159H, m, $\left(\mathrm{CH}_{3}\right)_{2}$ \& $\mathrm{NCHCH}_{2}$ \& $\left.\mathrm{OCH}_{2} \mathrm{CH}_{3}\right)$.

PVP150 $\delta_{\mathrm{H}}\left(300 \mathrm{MHz}, \mathrm{CDCl}_{3}\right) 4.11-3.46\left(150 \mathrm{H}, \mathrm{m}, \mathrm{NCH}_{2}\right)$, 3.46-2.92 (305H, m, NC(O) $\left.\mathrm{CH}_{2}\right)$ 2.85-2.75 (4H, m, C $(\mathrm{O})-$ $\left.\mathrm{CH}_{2} \mathrm{CH}_{2} \mathrm{C}(\mathrm{O})\right), 2.69-2.12\left(428 \mathrm{H}, \mathrm{m}, \mathrm{NC}(\mathrm{O}) \mathrm{CH}_{2}\right), 2.12-1.84$ $\left(320 \mathrm{H}, \mathrm{m}, \mathrm{NCH}_{2} \mathrm{CH}_{2}\right), 1.84-1.17\left(306 \mathrm{H}, \mathrm{m},\left(\mathrm{CH}_{3}\right)_{2} \& \mathrm{NCHCH}_{2}\right.$ \& $\left.\mathrm{OCH}_{2} \mathrm{CH}_{3}\right)$.

Representative Poly( $N$-vinylpyrrolidone) (PVP80) Glycan Functionalization. $26.6 \mathrm{mg}(2.8 \mu \mathrm{mol})$ of polymer and $21.2 \mathrm{mg}$ $(0.099 \mathrm{mmol})$ of galactosamine $\mathrm{HCl}$ were dissolved in the minimum amount of DMSO and $37.5 \mu \mathrm{L}$ of TEA, stirred for 3 days at RTP, and dialyzed using $0.5-1 \mathrm{kDa}$ regenerated cellulose membrane tubing in water. The dialyzed product was freeze-dried overnight to give a paleyellow powder $(23.5 \mathrm{mg})$.

$\delta_{\mathrm{H}}\left(300 \mathrm{MHz}, \mathrm{CDCl}_{3}\right) 5.35-4.75$ (anomeric $1 \mathrm{H}, \mathrm{m}, \mathrm{C}(\mathrm{O}) \mathrm{OH}$ ), 4.04-3.51 (84H, m, CHN \& glycan protons), 3.38-2.96 (184H, m, $\mathrm{NCH}_{2}$ \& glycan protons), 2.51-2.11 (176H, m, $\mathrm{NC}(\mathrm{O}) \mathrm{CH}_{2}$ \& glycan protons), $2.11-1.84\left(172 \mathrm{H}, \mathrm{m}, \mathrm{NCH}_{2} \mathrm{CH}_{2}\right), 1.84-1.01$ $\left(215 \mathrm{H}, \mathrm{m},\left(\mathrm{CH}_{3}\right)_{2} \& \mathrm{NCHCH}_{2} \& \mathrm{OCH}_{2} \mathrm{CH}_{3}\right)$. FTIR $\left(\mathrm{cm}^{-1}\right)$ 2920, 2877 (alkyl stretch) 1655 (lactam amide), $1422\left(\mathrm{CH}_{2}\right)$

Representative Poly( $\mathrm{N}$-vinylpyrrolidone) (PVP80) Biotin Functionalization. A $6.5 \mathrm{mg}(0.7 \mu \mathrm{mol})$ portion of polymer, $5 \mathrm{mg}$ $(17.46 \mu \mathrm{mol})$ of amino-functionalised biotin, and $27.5 \mu \mathrm{L}$ of TEA were dissolved in the minimum volume of DMSO and stirred at RTP for $72 \mathrm{~h}$. The reaction mixture was dialyzed using $1 \mathrm{kDa}$ regenerated cellulose membrane in water and freeze-dried to give a white solid $(5.6 \mathrm{mg}) . \delta_{\mathrm{H}}\left(300 \mathrm{MHz}, \mathrm{CDCl}_{3}\right) 4.08-3.52(82 \mathrm{H}, \mathrm{m}, \mathrm{CHN} \&$ $\left.\mathrm{C}(\mathrm{O}) \mathrm{NHCH}_{2}\right), 3.42-2.97\left(167 \mathrm{H}, \mathrm{NCH}_{2}, \mathrm{CHCHS}, \mathrm{CH}_{2} \mathrm{NH}_{2}\right.$, $\mathrm{CHCHHS}, \mathrm{CHCHHS}), 2.55-2.12\left(226 \mathrm{H}, \mathrm{NC}(\mathrm{O}) \mathrm{CH}_{2} \& \mathrm{CH}_{2} \mathrm{C}-\right.$ $(\mathrm{O}) \mathrm{NH}), 2.12-1.85\left(180 \mathrm{H}, \mathrm{NCH}_{2} \mathrm{CH}_{2}\right), 1.85-1.07(193 \mathrm{H}, \mathrm{m}$, $\left(\mathrm{CH}_{3}\right)_{2}, \quad \mathrm{NCHCH}, \quad \mathrm{OCH}_{2} \mathrm{CH}_{3}, \quad \mathrm{SCHCH}_{2} \mathrm{CH}_{2} \mathrm{CH}_{2}$ \& $\left.\mathrm{SCHCH}_{2} \mathrm{CH}_{2} \mathrm{CH}_{2}\right)$. FTIR $\left(\mathrm{cm}^{-1}\right) 1634$ (lactam amide)

\section{Lateral Flow Strip Running Protocol and Analysis}

A more detailed summary of dipstick manufacture, running, and analysis can be found in the Supporting Information, summarized here. Test lines were added and dried onto the dipsticks; in flow-through, the analyte was deposited in place of a test line. $50 \mu \mathrm{L}$ of running buffer (either with or without analyte) was agitated on a roller for $5 \mathrm{~min} .45$ $\mu \mathrm{L}$ of running buffer was added to a PCR tube, and a dipstick was added to the tube, so the dipstick protrudes from the top and the immobile phase $(1 \mathrm{~cm}$ from nonwick end) is not below the solvent line. There was one test per tube, and each test was run for $20 \mathrm{~min}$ before drying at room temperature for $5 \mathrm{~min}$. All tests were run in triplicate. All strips were scanned and exported to pdf before conversion to a jpeg file. The jpeg files were analyzed using ImageJ $1.51^{44}$ using the plot profile function to create a data set exported to Microsoft Excel for Mac. The data was exported to Origin 2019 64Bit, aligned, and averaged (mean). The data was then reduced by number of groups to 100 data points (nitrocellulose and wick) and plotted as gray value (scale) vs relative distance along the 100 data points.

\section{ASSOCIATED CONTENT}

\section{Supporting Information}

The Supporting Information is available free of charge at https://pubs.acs.org/doi/10.1021/acspolymersau.1c00032.

Details of materials and characterization techniques used; polymer, glycan, and gold nanoparticle synthesis and characterization (DLS, UV-vis, NMR, SEC, FTIR, mass spectroscopy, TEM, and XPS); details of lateral flow dipstick and cassette construction, running and analysis methods used; raw scans of the lateral flow devices, analyzed data and signal-to-noise calculations (PDF) 


\section{AUTHOR INFORMATION}

\section{Corresponding Author}

Matthew I. Gibson - Department of Chemistry, University of Warwick, CV4 7AL Coventry, U.K.; Warwick Medical School, University of Warwick, CV4 7AL Coventry, U.K.; ○ orcid.org/0000-0002-8297-1278; Email: m.i.gibson@ warwick.ac.uk

\section{Authors}

Alexander N. Baker - Department of Chemistry, University of Warwick, CV4 7AL Coventry, U.K.; (1) orcid.org/00000001-6019-3412

Thomas R. Congdon - Department of Chemistry, University of Warwick, CV4 7AL Coventry, U.K.; Warwick Medical School, University of Warwick, CV4 7AL Coventry, U.K.

Sarah-Jane Richards - Department of Chemistry, University of Warwick, CV4 7AL Coventry, U.K.

Panagiotis G. Georgiou - Department of Chemistry, University of Warwick, CV4 7AL Coventry, U.K.; (1) orcid.org/0000-0001-8968-1057

Marc Walker - Department of Physics, University of Warwick, CV4 7AL Coventry, U.K.

Simone Dedola - Iceni Diagnostics Ltd, Norwich NR4 7GJ, U.K.

Robert A. Field - Iceni Diagnostics Ltd, Norwich NR4 7GJ, U.K.; Department of Chemistry and Manchester Institute of Biotechnology, University of Manchester, Manchester M1 7DN, U.K.

Complete contact information is available at: https://pubs.acs.org/10.1021/acspolymersau.1c00032

\section{Notes}

The authors declare the following competing financial interest(s): R.A.F. is a director and shareholder of Iceni Diagnostics Ltd.

Data Access Statement: The research data supporting this publication can be found at http://wrap.warwick.ac.uk, and all images of test strips are in the Supporting Information.

\section{ACKNOWLEDGMENTS}

The BBSRC-funded MIBTP program (BB/M01116X/1) and Iceni Diagnostics ltd are thanked for a studentship for A.N.B. This project has received funding from the European Union's Horizon 2020 research and innovation programme under the Marie Skłodowska-Curie grant agreement No. 814236 (P.G.G.). BBSRC/Innovate are thanked for funding the Specialty Glycans project BB/M02878X/1 (S.J.R.). UoW, EPSRC (EP/R511808/1), and BBSRC (BB/S506783/1) impact acceleration accounts are thanked for supporting S.J.R./T.R.C. The Warwick Polymer Research Technology Platform is acknowledged for SEC analysis. M.I.G. is supported by the ERC (866056). The Warwick Polymer and Electron Microscopy Research Technology Platforms (Y. Han) are acknowledged for the SEC/EM analysis.

\section{REFERENCES}

(1) St John, A.; Price, C. P. Existing and Emerging Technologies for Point-of-Care Testing. Clin Biochem Rev. 2014, 35 (3), 155-167.

(2) Braunstein, G. D.; Khanlian, S.; Cole, L.; Wade, M. The Long Gestation of the Modern Home Pregnancy Test. Clin. Chem. 2014, 60 (1), 18-21.
(3) Crane, M. M.; Organon, M. V. Diagnostic Test Device. US3579306A, January 1969.

(4) Wu, J.; Ma, J.; Wang, H.; Qin, D.; An, L.; Ma, Y.; Zheng, Z.; Hua, X.; Wang, T.; Wu, X. Rapid and Visual Detection of Benzothiostrobin Residue in Strawberry Using Quantum Dot-Based Lateral Flow Test Strip. Sens. Actuators, B 2019, 283, 222-229.

(5) Yu, L.; Li, P.; Ding, X.; Zhang, Q. Graphene Oxide and Carboxylated Graphene Oxide: Viable Two-Dimensional Nanolabels for Lateral Flow Immunoassays. Talanta 2017, 165, 167-175.

(6) Hassan, A. H. A.; Bergua, J. F.; Morales-Narváez, E.; Mekoçi, A. Validity of a Single Antibody-Based Lateral Flow Immunoassay Depending on Graphene Oxide for Highly Sensitive Determination of E. Coli O157:H7 in Minced Beef and River Water. Food Chem. 2019, 297, 124965.

(7) Yao, L.; Teng, J.; Zhu, M.; Zheng, L.; Zhong, Y.; Liu, G.; Xue, F.; Chen, W. MWCNTs Based High Sensitive Lateral Flow Strip Biosensor for Rapid Determination of Aqueous Mercury Ions. Biosens. Bioelectron. 2016, 85, 331-336.

(8) Carrio, A.; Sampedro, C.; Sanchez-Lopez, J.; Pimienta, M.; Campoy, P. Automated Low-Cost Smartphone-Based Lateral Flow Saliva Test Reader for Drugs-of-Abuse Detection. Sensors 2015, 15 (11), 29569-29593.

(9) Wonderly, B.; Jones, S.; Gatton, M. L.; Barber, J.; Killip, M.; Hudson, C.; Carter, L.; Brooks, T.; Simpson, A. J. H.; Semper, A.; Urassa, W.; Chua, A.; Perkins, M.; Boehme, C. Comparative Performance of Four Rapid Ebola Antigen-Detection Lateral Flow Immunoassays during the 2014-2016 Ebola Epidemic in West Africa. PLoS One 2019, 14 (3), No. e0212113.

(10) Jarvis, J. N.; Percival, A.; Bauman, S.; Pelfrey, J.; Meintjes, G.; Williams, G. N.; Longley, N.; Harrison, T. S.; Kozel, T. R. Evaluation of a Novel Point-of-Care Cryptococcal Antigen Test on Serum, Plasma, and Urine from Patients with HIV-Associated Cryptococcal Meningitis. Clin. Infect. Dis. 2011, 53, 1019-1023.

(11) Carter, L. J.; Garner, L. V.; Smoot, J. W.; Li, Y.; Zhou, Q.; Saveson, C. J.; Sasso, J. M.; Gregg, A. C.; Soares, D. J.; Beskid, T. R.; Jervey, S. R.; Liu, C. Assay Techniques and Test Development for COVID-19 Diagnosis. ACS Cent. Sci. 2020, 6, 591.

(12) Posthuma-Trumpie, G. A.; Korf, J.; Van Amerongen, A. Lateral Flow (Immuno)Assay: Its Strengths, Weaknesses, Opportunities and Threats. A Literature Survey. Anal. Bioanal. Chem. 2009, 393 (2), 569-582.

(13) Baker, A. N.; Richards, S. J.; Guy, C. S.; Congdon, T. R.; Hasan, M.; Zwetsloot, A. J.; Gallo, A.; Lewandowski, J. R.; Stansfeld, P. J.; Straube, A.; Walker, M.; Chessa, S.; Pergolizzi, G.; Dedola, S.; Field, R. A.; Gibson, M. I. The SARS-COV-2 Spike Protein Binds Sialic Acids and Enables Rapid Detection in a Lateral Flow Point of Care Diagnostic Device. ACS Cent. Sci. 2020, 6 (11), 2046-2052.

(14) Damborský, P.; Koczula, K. M.; Gallotta, A.; Katrlík, J. LectinBased Lateral Flow Assay: Proof-of-Concept. Analyst 2016, 141 (23), 6444-6448

(15) Baker, A. N.; Richards, S.-J.; Pandey, S.; Guy, C. S.; Ahmad, A.; Hasan, M.; Biggs, C. I.; Georgiou, P. G.; Zwetsloot, A. J.; Straube, A.; Dedola, S.; Field, R. A.; Anderson, N. R.; Walker, M.; Grammatopoulos, D.; Gibson, M. I. Glycan-Based Flow-Through Device for the Detection of SARS-COV-2. ACS Sensors 2021, 6, 3696-3705

(16) Ishii, J.; Toyoshima, M.; Chikae, M.; Takamura, Y.; Miura, Y. Preparation of Glycopolymer-Modified Gold Nanoparticles and a New Approach for a Lateral Flow Assay. Bull. Chem. Soc. Jpn. 2011, 84 (5), 466-470.

(17) Mansfield, M. A. Nitrocellulose Membranes for Lateral Flow Immunoassays: A Technical Treatise. Lateral Flow Immunoassay 2009, 95-114.

(18) Mansfield, M. M. The Use of Nitrocellulose Membranes in Lateral Flow Assays. Drugs of Abuse: Body Fluid Testing 2005, 71-85.

(19) Aoyama, S.; Akiyama, Y.; Monden, K.; Yamada, M.; Seki, M. Thermally Imprinted Microcone Structure-Assisted Lateral-Flow Immunoassay Platforms for Detecting Disease Marker Proteins. Analyst 2019, 144 (5), 1519-1526. 
(20) Ledesma-Osuna, A. I.; Ramos-Clamont, G.; Vázquez-Moreno, L. Characterization of Bovine Serum Albumin Glycated with Glucose, Galactose and Lactose. Acta Biochim. Polym. 2008, 55, 491-497.

(21) Jorgensen, P.; Chanthap, L.; Rebueno, A.; Tsuyuoka, R.; Bell, D. Malaria Rapid Diagnostic Tests in Tropical Climates: The Need for a Cool Chain. Am. J. Trop. Med. Hyg. 2006, 74 (5), 750-754.

(22) Pai, N. P.; Vadnais, C.; Denkinger, C.; Engel, N.; Pai, M. Pointof-Care Testing for Infectious Diseases: Diversity, Complexity, and Barriers in Low- And Middle-Income Countries. PLoS Med. 2012, 9 (9), No. e1001306.

(23) Aung, M. N.; Koyanagi, Y.; Yuasa, M. Health Inequality among Different Economies during Early Phase of COVID-19 Pandemic. J. Egypt. Public Health Assoc. 2021, 96 (1), 3.

(24) Hansch, C.; Leo, A.; Hoekman, D. Exploring QSAR: Hydrophobic, Electronic, Steric Constants; ACS: Washington DC, 1995.

(25) Franco, P.; De Marco, I. The Use of Poly(N-Vinyl Pyrrolidone) in the Delivery of Drugs: A Review. Polymers 2020, 12 (5), 1114.

(26) Ieong, N. S.; Redhead, M.; Bosquillon, C.; Alexander, C.; Kelland, M.; O'Reilly, R. K. The Missing Lactam-Thermoresponsive and Biocompatible Poly (N -Vinylpiperidone) Polymers by XanthateMediated RAFT Polymerization. Macromolecules 2011, 44 (4), 886893.

(27) Congdon, T.; Notman, R.; Gibson, M. I. Antifreeze (Glyco)Protein Mimetic Behavior of Poly(Vinyl Alcohol): Detailed Structure Ice Recrystallization Inhibition Activity Study. Biomacromolecules 2013, 14 (5), 1578-1586.

(28) Perrier, S. 50th Anniversary Perspective: RAFT PolymerizationA User Guide. Macromolecules 2017, 50 (19), 7433-7447.

(29) Stenzel, M. H.; Cummins, L.; Roberts, G. E.; Davis, T. P.; Vana, P.; Barner-Kowollik, C. Xanthate Mediated Living Polymerization of Vinyl Acetate: A Systematic Variation in MADIX/RAFT Agent Structure. Macromol. Chem. Phys. 2003, 204 (9), 1160-1168.

(30) Congdon, T. R.; Notman, R.; Gibson, M. I. Influence of Block Copolymerization on the Antifreeze Protein Mimetic Ice Recrystallization Inhibition Activity of Poly (Vinyl Alcohol). Biomacromolecules 2016, 17 (9), 3033-3039.

(31) Keddie, D. J.; Moad, G.; Rizzardo, E.; Thang, S. H. RAFT Agent Design and Synthesis. Macromolecules 2012, 45 (13), 53215342.

(32) Bell, C. A.; Hedir, G. G.; O'Reilly, R. K.; Dove, A. P. Controlling the Synthesis of Degradable Vinyl Polymers by XanthateMediated Polymerization. Polym. Chem. 2015, 6 (42), 7447-7454.

(33) Eisenführ, A.; Arora, P. S.; Sengle, G.; Takaoka, L. R.; Nowick, J. S.; Famulok, M. A Ribozyme with Michaelase Activity. Bioorg. Med. Chem. 2003, 11 (2), 235-249.

(34) Kaufman, N. E. M.; Meng, Q.; Griffin, K. E.; Singh, S. S.; Dahal, A.; Zhou, Z.; Fronczek, F. R.; Mathis, J. M.; Jois, S. D.; Vicente, M. G. H. Synthesis, Characterization, and Evaluation of Near-IR Boron Dipyrromethene Bioconjugates for Labeling of Adenocarcinomas by Selectively Targeting the Epidermal Growth Factor Receptor. J. Med. Chem. 2019, 62 (7), 3323-3335.

(35) Richards, S.-J.; Gibson, M. I. Optimization of the Polymer Coating for Glycosylated Gold Nanoparticle Biosensors to Ensure Stability and Rapid Optical Readouts. ACS Macro Lett. 2014, 3 (10), 1004-1008.

(36) Richards, S. J.; Keenan, T.; Vendeville, J. B.; Wheatley, D. E.; Chidwick, H.; Budhadev, D.; Council, C. E.; Webster, C. S.; Ledru, H.; Baker, A. N.; Walker, M.; Galan, M. C.; Linclau, B.; Fascione, M. A.; Gibson, M. I. Introducing Affinity and Selectivity into GalectinTargeting Nanoparticles with Fluorinated Glycan Ligands. Chem. Sci. 2021, 12 (3), 905-910.

(37) Pancaro, A.; Szymonik, M.; Georgiou, P.; Baker, A. N.; Walker, M.; Adriaensens, P.; Hendrix, J.; Gibson, M. I.; Nelissen, I. The Polymeric Glyco-Linker Controls the Signal Outputs for Plasmonic Gold Nanorods Biosensors Due to Biocorona Formation. Nanoscale 2021, 13, 10837-10848.

(38) Bahadır, E. B.; Sezgintürk, M. K. Lateral Flow Assays: Principles, Designs and Labels. TrAC, Trends Anal. Chem. 2016, 82, 286-306.
(39) Alfthan, H.; Björses, U.-M.; Tiitinen, A.; Stenman, U.-H. Specificity and Detection Limit of Ten Pregnancy Tests. Scand. J. Clin. Lab. Invest. 1993, 53, 105-113.

(40) Green, N. M. Avidin. Adv. Protein Chem. 1975, 29, 85-133.

(41) Baker, A. N.; Muguruza, A. R.; Richards, S.-J.; Georgiou, P. G.; Goetz, S.; Walker, M.; Dedola, S.; Field, R. A.; Gibson, M. I. Lateral Flow Glyco-Assays for the Rapid and Low-Cost Detection of Lectins - Polymeric Linkers and Particle Engineering are Essential for Selectivity and Performance. Adv. Healthcare Mater. 2021, 2101784.

(42) Lundquist, J. J.; Toone, E. J. The Cluster Glycoside Effect. Chem. Rev. 2002, 102 (2), 555-578.

(43) Simon, S.; Worbs, S.; Avondet, M.-A.; Tracz, D.; Dano, J.; Schmidt, L.; Volland, H.; Dorner, B.; Corbett, C. Recommended Immunological Assays to Screen for Ricin-Containing Samples. Toxins 2015, 7 (12), 4967-4986.

(44) Schneider, C. A.; Rasband, W. S.; Eliceiri, K. W. NIH Image to ImageJ: 25 Years of Image Analysis. Nat. Methods 2012, 9 (7), 671675. 